\title{
Moving on
}

\author{
Jennie Mather
}

\section{As a company grows, the founding scientist sometimes discovers (and investors often hint) that it's time to leave the CEO spot and hand it to someone with more business experience. To ease the possible shock of the process, consider this transition from day one.}

$\mathrm{M}$ any scientific founders of biotech startups begin as the CEO. This makes a good deal of sense because there is no one as well versed in the scientific and business potential of a new technology or a brilliant platform as the founder, and no one else can represent these advantages as wholeheartedly to potential investors. In fact, many founders prefer to be CEO because it gives them scientific and cultural control over the direction of the company. Also, because scientists are people who often enjoy stretching their horizons by learning and experimenting with new ideas and skills, the challenge of creating a successful scientific-based commercial enterprise is very appealing. Additionally, scientists tend to believe, with perhaps more confidence than is warranted, that 'good science' ultimately wins out no matter who is at the helm. In many ways a scientist as CEO is a good fit for a technology-driven company.

But as the start-up grows and the company's needs and board composition change, the character of the CEO job morphs as well. Ironically, the founder-CEO who is most successful at raising money, growing the company and moving toward a commercial product is usually the first to come up against the issue of leadership succession. So it's best to just assume that the issue will arise.

There seems to be a broadly held perception in the venture capital (VC) community that scientists do not make good CEOs, even though there have been highly visible successes of scientist-CEOs at some very large companies (South San Francisco-based

Jennie Mather was founder and CEO of Raven Biotechnologies from 1999-2006. She is now senior vice president of Macrogenics,

1 Corporate Dr., South San Francisco, CA

94080, USA

e-mail:matherj@macrogenics.com
Genentech included). There also is an apparent bias against founders remaining in the lead role as the company moves toward commercial success; in particular, VCs universally assume that scientist-founders should not continue as CEO.

In fact, this issue often arises as early as the first rounds of funding. Be prepared for the question: "Are you open to finding a new CEO in the future?" Though the pat answer of "I will do what's best for the company" allows both VC and founder to move on to more comfortable topics, more honest answers would be: "I want to remain a CEO and grow this company"; "I would like to take the company public" or "I'd like to get someone in the CEO role as soon as we are funded so I can concentrate on the science."

So it's key to start thinking about the answer long before the question comes up, because VCs aren't necessarily going to be looking out for you (Box 1). The best chance of making a successful transition is to think of what is most important to you early and often.

I moved Raven from start-up through four funding rounds that totaled $\$ 115$ million. We secured four partnerships based around our antibodies and antibody discovery engine. We validated the discovery platform and took one product into phase 2 trials, with three more products in the pipeline. Although I had never planned to remain CEO when the company went public, the board wanted a change earlier than I thought was in the best interest of the company. I also had been thinking of putting in place a CEO from inside the company, whereas the board was thinking of bringing in an outside candidate. Because this had not been fully discussed from the very beginning, the discussions were more difficult than they should have been. Eventually we took in a new CEO from outside (whereas I stayed on as president and chief scientific officer) and the com- pany recently was acquired by Macrogenics, a private biotech company on the East Coast (Table 1). From these experiences, I've come up with five steps that should lead to a successful transition-whether it is initiated by the founder or the board of directors.

\section{Step 1: plan early}

It is never too early to start planning the transition. When you draft the documents for your first financing, you should already have considered what role you want to play going forward, how you want to transition and when. A financing term sheet (and the documents that follow it) will clearly define the company's ownership and who holds board seats. It will also define who votes on what issues and what the voting threshold is for approval of different corporate actions, such as borrowing money, appointing directors, issuing stock, making a partnership deal, selling the company or any other legally binding contracts the company enters into. If you want to have an employment contract or be on the board of directors, among other things, then it is best to put this all in writing and incorporate it into the financing documents; that way negotiations can be part of the entire financing package.

\section{Step 2: decide what you really want}

The most important part of this planning is to be aware of your desires. Do you want to leave the company at the transition? Do you want to stay connected (via a board seat) but not work at the company? Do you want to keep a major ongoing role in the company, such as chief scientific officer?

When you have the answers to these questions, work with your lawyer and your board on a transition plan. This is a good time to draw up an employment contract-a document that protects the interests of the employee and often is typical at larger compa- 


\section{Box 1 Dealing with venture capitalists}

It's true that venture capitalists (VCs) funding new companies don't always talk with or listen to the founders concerning what role they want to play. First-time scientist-founders may not know much about venture financing and what the VCs' needs and issues are, so founders may well appreciate some coaching in the art of running a business from people who deal with start-ups on a daily basis. The problem is that VCs in general are not very good at initiating these discussions, though they would be beneficial to both the VC and the companies they support. If a conversation does occur, and if the VCs' and founder's ideas are widely different concerning an exit strategy or governance, then perhaps it is not wise to engage in that relationship at all. Even when the management, founders and investors are all in agreement on the goals of the company, building a start-up is not simple or easy.

nies, although it is not always in place (or even mentioned) at start-ups or private companies. This contract covers what the company offers you in the event that your job description is substantially and adversely affected. It may be tied to your tenure at the company or associated with the company meeting certain milestones. The payout can be triggered by your departure (if you are fired 'without cause') or in the event of the company's location being moved more than a certain distance from its current locale. It also can be triggered by your title, compensation and/or duties being substantially reduced (such as the appointment of a new CEO, your dismissal from the board or your decision to leave after the appointment of a new CEO).

Payout in these plans can include severance (a certain percentage of your annual salary paid as a lump sum or over time), continued health care coverage and accelerated vesting of stock options or extended time to purchase stock options. You should consider consulting outside counsel specializing in employment law to help draw up this document (the company should be willing to cover reasonable costs for this). Remember that corporate counsel works for the company, not for you.
If you are planning to remain connected to the company as an employee or a board member, then you should get a written agreement from the investors about what that role should be. It is the board's job to hire the CEO. However, you and the current management team will be working daily with that new CEO, so it's important that both you and your management team are comfortable with the new hire. Put in place an agreement that includes you on the search committee. As founder and future member of the management team, you should have a real voice in any hiring decision. It's possible to put in the employment contract language specifying that a CEO hire done without your approval becomes a trigger for your departure, with severance.

Before you start the search, draw up a description of what CEO characteristics you are looking for. (This might also help you and the board discuss your current role as CEO and the board's expectations.) At all times, even very early in the life of the company, keep your eyes open for good search firms and potential CEO candidates. You will be spending a lot of time with candidates and recruiters as you fill out your management team, so use this time to help refine your ideal replacement description.

\section{Table 1 CEO transition timeline}

\begin{tabular}{|c|c|}
\hline Year & Action \\
\hline 1999 & Established Raven Biotechnologies; first financing Q2 of 1999 \\
\hline $1999-2000$ & Technical proof of concept for discovery platform; second financing Q4 of 2000 \\
\hline $2001-2002$ & Discovery efforts continue; third financing Q4 of 2002 \\
\hline 2003 & Several products identified; first candidate moved to preclinical development \\
\hline \multirow[t]{2}{*}{2004} & $\begin{array}{l}\text { Started CEO search in Q1; drafted letter of understanding with board regarding my } \\
\text { involvement in both the CEO search and company growth }\end{array}$ \\
\hline & Filed investigational new drug application in Q4; initiated phase 1 trial in Q4 \\
\hline \multirow[t]{2}{*}{2005} & Stopped CEO search in Q1; started fourth financing round \\
\hline & Closed financing in Q3; resumed CEO search \\
\hline 2006 & New CEO appointed in Q2; I moved to president, director and chief scientific officer \\
\hline 2007 & $\begin{array}{l}\text { Started search for merger partner in Q4; drafted change in control agreement } \\
\text { between board and management }\end{array}$ \\
\hline 2008 & Merger completed with Macrogenics in Q3 \\
\hline
\end{tabular}


will be with the company after the new CEO arrives. This is where having a transition plan and employment contract in writing can be very important. If you can't get everything you want, then carefully think through the situation and prioritize what is most important to you, the board and the company. Be willing to compromise so everyone feels they have some of what they want most.

\section{Step 5: after the transition}

If you are going to stay on with the company, especially in a chief scientific officer role, then your job is not finished when the new CEO arrives. You should have worked out clearly defined areas of responsibility before his or her hire, but also take the opportunity to do so once the CEO is in place and do it in writing. This can also be done in the context of setting goals for the entire company and planning for daily or weekly meetings to facilitate communication. If all of this is in writing, the board, the new CEO, the employees and you should all start on the same page. Still, as the founder, there will be occasions in which employees come to you to ask for help, complain or request intervention. If the issue is not within your agreed area, then do not get involved. Refer them to the new CEO. If it is within your area of responsibility, then solve the problem and communicate the result.

Now, what if your new role in the company is not fulfilling? Then it is probably best to cut ties and find another opportunity elsewhere. This is where having an employment contract can be of value if it allows you to leave, with severance, before the situation gets too sticky. However, there can also be a great deal of satisfaction in having the opportunity to refocus attention on the science as the company continues to grow. After all, most of us are in science because we find it one of the most challenging and satisfying occupations. Add to that the ability to create high-quality jobs, a stimulating work environment and the capacity to impact the health and well being of patients, and that makes creating and working in start-up biotech businesses positively addicting.

\section{Conclusion}

There will always be the need for a leadership transition in a successful company whether it comes through business growth, business refocusing or just time. It may come sooner for a scientist-founder due to the perception or reality of business needs shifting away from the proof of scientific principle and toward partnerships and sales. The success of this transition can determine the eventual success of the company. Both the investors and the founding CEO should honestly and openly discuss this issue early in the history of the company and review the situation together periodically. How you and the investors manage the succession may be one of the most important things you do in determining the long-term success of the company. 